\title{
Analisis Variasi Genetik Melon (Cucumis melo L.) Kultivar Gama Melon Basket Dengan Metode Random Amplified Polymorphic DNA
}

\author{
IKHSAN NUR HUDA ${ }^{1}$, BUDI SETIADI DARYONO ${ }^{1}$ \\ ${ }^{1}$ Laboratorium Genetika, Fakultas Biologi, Universitas Gadjah Mada \\ Jl. Teknika Selatan Sekip Utara Sleman Yogyakarta 55281 \\ email: huda.inh@gmail.com
}

\begin{abstract}
Melon (Cucumis melo L.) cultivars Gama Melon Basket (GMB) is the result of plant breeding that has the potential to be a product of local melon seed in Indonesia. This cultivar phenotype characters was known, but its genetic variation is not further studied. This study aimed to analyze the genetic variation of melon cultivars GMB and compared with 13 commercial melons and four members of the family Cucurbitaceae such as; cucumber, cucumber queen, barteh, and cantaloupe (blewah). RAPD-PCR method with 11 random primer was used to evaluate genetic variation in melon. Level of genetic similarity was determined by the formula simple matching coefficient (SSM) and the dendogram constructed by clustering analysis unweighted pair-group using arithmetic averages (UPGMA). Results of RAPD-PCR with 11 primer produced 165 loci and it contains 84.85 $\%$ polymorphic DNA and $15.15 \%$ monomorphic DNA. Results of genetic variation analysis suggests that 15 commercial melons differ from groups of cucumber, cucumber queen, barteh and cantaloupe (blewah). Cultivars GMB has genetic marker that can be distinguished from other commercial melons. GMB cultivar have specific polymorphic DNA on the size of 285 bp generated by PMAR primer.
\end{abstract}

Keywords: Cucumis melo L., Gama Melon Basket, genetic variation, RAPD

\section{PENDAHULUAN}

Data dari Direktorat Jenderal Hortikultura (2008) menyatakan bahwa produktivitas buah melon di Indonesia dari tahun 2003-2007 cenderung menurun. Pada tahun 2003, produksi melon mencapai 70.560 ton. Tahun 2004 hasil panen menurun drastis menjadi 47.664 ton yang disebabkan berkurangnya luas lahan untuk pertanian melon, yaitu 2.287 ha. Tahun 2005 produksi buah melon nasional mencapai 58.440 ton dengan luas panen 3.245 ha dan rata-rata hasil 18,01 ton/ha. Tahun 2006 produksi melon menurun menjadi 55.370 ton dengan luas panen 3.189 ha dan rata-rata hasil 17,36 ton/ha. Selanjutnya pada tahun 2007 , produksi melon hanya mencapai 57.725 ton atau sekitar 16,45 ton/ha, lebih rendah dari tahun 2003. Penurunan produksi melon ini diakibatkan oleh serangan hama dan penyakit, teknik budidaya yang belum memadai dan masih sedikitnya daerah sentra pertanian melon di Indonesia.
Pengembangan pemuliaan tanaman melon di Indonesia telah banyak dilakukan, khususnya untuk merakit kultivar lokal yang unggul dan memiliki nilai jual di masyarakat. Para petani pada umumnya akan membudidayakan melon yang menjadi unggulan di masyarakat, misalnya melon dengan rasanya yang manis, warna dagingnya orange, ukuran buah besar, dan memiliki daya simpan yang lama. Benih melon yang digunakan petani juga masih bergantung dengan benih melon impor seperti dari Jepang, Korea, dan Taiwan (Astuti, 2007). Dengan demikian sangat penting peranan para pemulia tanaman melon untuk memproduksi kultivar unggulan yang dapat bersaing dengan kultivar impor. Tujuan dari perakitan melon unggul adalah untuk menghasilkan melon yang unggul dari sifat morfologis maupun ketahanannya terhadap hama dan penyakit, sehingga dapat mengurangi ketergantungan petani terhadap benih melon impor. 
Untuk menentukan sifat dari suatu kultivar melon tidak cukup dilihat dari karakter morfologinya, tetapi dapat dianalisis pada aras molekularnya. Sesuai dengan perkembangan teknik genetika molekular, variasi genetik dapat diketahui melalui analisis DNA-nya (Garcia et al., 1998). Pada penelitian sebelumnya (Huda, 2009), yaitu perakitan melon kultivar Gama Melon Basket (GMB) (Nugraha, 2009) telah sampai pada analisis variasi fenotip berdasarkan morfologi dan biokimiawinya. Kultivar tersebut menunjukkan sifat yang berbeda berdasarkan karakter fenotipiknya. Demikian juga jika dibandingkan dengan kultivar komersial lainnya yang biasa dibudidayakan di Indonesia. Kestabilan gen yang mengontrol fenotipnya dan hubungan kekerabatan yang dapat menjadi pembeda diantara kultivar melon tersebut dapat diketahui dengan menganalisis variasi genetiknya.

Data variasi genetik berbagai kultivar melon, dapat dianalisis berdasar penanda molekular dengan metode Random Amplified Polymorphic DNA (RAPD). RAPD adalah salah satu teknik molekular berbasis Polymerase Chain Reaction (PCR) untuk menganalisis variasi genetik suatu spesies atau populasi yang dapat dilihat dari ada atau tidaknya pita DNA polimorfik dan monomorfik (Prana dan Hartanti, 2003). Berdasarkan analisis tersebut, maka diharapkan dalam penelitian ini dapat memperoleh ciri genetik pembeda dari kultivar Gama Melon Basket yang dibandingkan dengan kultivar melon komersial lainnya.

\section{METODE}

Penanaman melon. Perkecambahan biji melon. Biji tanaman dari 18 kultivar disiapkan, yaitu kultivar GMB, PI 371795, Andes, Action 434, Glamour, MAI, Ladika, Astroz, Sumo, Monami Red, Elegant, Fantasy, Sky Rocket, Virgo, timun, timun suri, barteh, dan blewah. Masing-masing kultivar diambil 5 biji. Selanjutnya biji dikecambahkan pada nampan yang dilapisi kain handuk basah. Letaknya disusun berdasarkan jenis kultivar dan diberi label untuk membedakannya. Kemudian biji disimpan pada suhu kamar selama 24-48 jam sampai biji berkecambah. Biji berkecambah ditandai dengan keluarnya radikula dari kulit biji. Penanaman dan perawatan tanaman di dalam greenhouse. Biji melon yang telah berkecambah dipindahkan ke dalam medium tanah pada polybag. Setiap polybag ditanami satu kecambah melon dan diberi label sesuai nama kultivarnya. Setelah tanaman berumur kurang lebih 4-5 minggu, daun dapat dikoleksi untuk diisolasi DNA-nya

Koleksi sampel daun. Setelah 4-5 minggu ditanam, dipilih daun ke-3, 4, atau ke 5 dari apikal yang segar dan bebas infeksi jamur maupun virus untuk dipotong sebagai sampel penelitian. Pemilihan daun yang bebas infeksi jamur dan virus dimaksudkan agar DNA yang diperoleh terhindar dari kontaminasi asam nukleat dari jamur maupun virus. Daun dari 18 kultivar melon dimasukkan ke dalam kantong plastik dan disimpan dalam freezer pada suhu $-20^{\circ} \mathrm{C}$. Sampel daun siap digunakan untuk diekstraksi DNA-nya.

Ekstraksi DNA. Kit ekstraksi DNA (Illustra Nucleon Phytopure Genomic DNA Extraction Kits seri RPN8511) digunakan sebagai metode untuk mengisolasi DNA 18 kultivar sampel. Sampel daun 18 kultivar diambil dari freezer kemudian ditimbang seberat $0,1-0,5$ gr. Selanjutnya digerus dengan menggunakan mortar sampai lembut. Setelah sampel lembut, ditambahkan $500 \mu \mathrm{L}$ Reagen PHYTOPURE I di atas mortar kemudian diratakan dan digerus kembali secara perlahan. Campuran yang telah halus dituangkan pada tube 1,5 mL dan ditambahkan $400 \mu \mathrm{L}$ Reagen PHYTOPURE II dan dikocok dengan lembut sampai tercampur sempurna. Selanjutnya diinkubasikan pada suhu $65^{\circ} \mathrm{C}$ selama 10 menit dalam gelas beker berisi air di atas pemanas hot plate kemudian dimasukkan dalam ice box selama 20 menit. Setelah itu, ditambahkan $400 \mu \mathrm{L}$ chlorofom dingin dan ditambahkan $20 \mu \mathrm{L}$ Resin PHYTOPURE. Tube disentrifuge selama 10 menit dengan kecepatan $3.000 \mathrm{rpm}$. Hasil dari sentrifuge di dapatkan 3 lapisan yang terdiri dari supernatant, komplek resin dan debris sel, dan chlorofom. Supernatant yang dihasilkan kemudian diambil dan dipindahkan ke dalam tube baru yang telah disiapkan. Isopropanol 
dingin ditambahkan melalui dinding tube, isopropanol yang ditambahkan sama dengan volume supernatant yang diambil atau sama dengan perbandingan $1: 1$, selanjutnya dikocok perlahan sampai terlihat benang-benang halus DNA. Tahap selanjutnya, tube disentrifuge dengan kecepatan $10.000 \mathrm{rpm}$ selama 10 menit. Setelah itu dihasilkan pellet DNA berwarna putih pada dasar tube. Supernatant dibuang dan pelet dicuci dengan $100 \mu \mathrm{L}$ ethanol $70 \%$. Pelet disentrifuge kembali untuk pencucian dengan kecepatan $10.000 \mathrm{rpm}$ selama 5 menit, pencucian ini dilakukan sebanyak 3 kali. Ethanol dibuang, pelet DNA dikeringkan, kemudian ditambahkan TE 1 X 50 $\mu \mathrm{L}$. Hasil ekstraksi DNA disimpan dalam freezer $\left(-20^{\circ} \mathrm{C}\right)$ dan siap untuk digunakan pada tahap selanjutnya.

\section{Uji kuantitatif DNA hasil ekstraksi.} Sebelum diukur konsentrasi dan kemurnian sampel DNA, dilakukan pengenceran DNA. Sampel DNA yang akan diukur diambil $2 \mu l$ dan dimasukkan ke dalam tube 1,5 $\mathrm{ml}$. selanjutnya ditambahkan akuabides sebanyak $98 \mu \mathrm{l}$ (faktor pengenceran 50 kali). Larutan blanko yang digunakan adalah akuabides. Larutan blanko diambil $100 \mu \mathrm{l}$, kemudian spektrofotometer diatur pada panjang gelombang $260 \mathrm{~nm}$, selanjutnya ditekan tombol auto zero sehingga pada monitor akan menunjukkan angka nol. Selanjutnya akuabides diganti dengan sampel DNA yang telah diencerkan sebelumnya dan absorbansinya diukur pada panjang gelombang $260 \mathrm{~nm}$ yang ditunjukkan oleh angka pada monitor. Setelah itu sampel DNA diambil dan diganti dengan larutan blanko, kemudian di kaliberasi pada panjang gelombang $280 \mathrm{~nm}$ sampai menunjukkan angka nol pada monitor. Larutan blanko diambil, diganti dengan sampel DNA untuk diukur absorbansinya. Pengukuran absorbansi pada panjang gelombang $260 \mathrm{~nm}$ dan $280 \mathrm{~nm}$ dilakukan dua kali ulangan.

Pengenceran DNA template. Sebelum diamplifikasi, DNA template diencerkan terlebih dahulu dengan menambahkan larutan TE 1X. Berdasarkan optimasi yang telah dilakukan sebelumnya, konsentrasi DNA template yang digunakan adalah $70 \mu \mathrm{g} / \mathrm{mL}$.
Amplifikasi DNA dengan metode PCRRAPD. Sebelum dilakukan amplifikasi DNA, disiapkan bahan seperti DNA template, primer RAPD (Tabel 1), akuabides steril, dan FastStart PCR Master yang disimpan dalam icebox. Premix PCR dibuat dengan komposisi seperti pada Tabel 2. Premix PCR dibuat sesuai dengan jumlah sampel yang akan di PCR. Semua ramuan untuk premix PCR dimasukkan dalam satu tube 1,5 $\mathrm{ml}$ tanpa menambahkan DNA template. Setelah semua ramuan dicampur sampai homogen kemudian dibagi dalam tube $0,2 \mathrm{ml}$ yang baru sesuai dengan jumlah sampel yang akan di PCR, dengan volume total dikurangi volume DNA template. Selanjutnya DNA template ditambahkan pada masing-masing tube dan dihomogenkan dengan vortex berkecepatan rendah. Tube yang berisi DNA dan komponen formula PCR kemudian diamplifikasi dalam mesin PCR BOECO Thermal Cycler TC-PRO (Jerman) dengan pengaturan seperti pada Tabel 3. Reaksi dalam mesin PCR akan berjalan selama 4 jam dengan jumlah siklus 45 kali. Setelah mesin PCR berhenti, sampel produk PCR dikeluarkan dan disimpan di dalam freezer $\left(-20^{\circ} \mathrm{C}\right)$.

Analisis hasil amplifikasi PCR-RAPD dengan elektroforesis. Sampel DNA produk PCR RAPD, gel agarosa $2 \%$, loading dye dan marker 100 bp (Fermentas, Kanada; Bioron, Jerman; dan Vivantis, Malaysia) disiapkan. Dibuat campuran masing-masing sampel DNA di atas kertas parafin dengan perbandingan $5 \mu 1$ sampel DNA dan $1 \mu 1$ loading dye. Sampel DNA dimasukkan ke dalam sumuran ke 2 dan seterusnya sesuai jumlah sampel, sedangkan sumuran ke-1 diisi marker. Voltase diatur 50 volt. Setelah migrasi DNA mencapai 2/3 panjang gel dengan waktu kurang lebih 70-75 menit, maka mesin dimatikan. Gel diambil kemudian direndam dalam larutan ethidium bromide selama 20-30 menit. Gel hasil elektroforesis diamati dengan UV Transilluminator. Pita-pita DNA yang terbentuk akan tampak sebagai sinyal berwarna merah muda dengan intensitas yang berbeda sesuai dengan besarnya konsentrasi DNA. Visualisasi pita-pita DNA hasil 
elektroforesis difoto menggunakan kamera digital.

Pengolahan gambar hasil visualisasi DNA. Gambar hasil visualisasi DNA diedit dengan menggunakan program Corel Photo Paint X3 untuk diatur kontras dan ketajaman warnanya agar terlihat lebih jelas. Foto berwarna yang telah diedit kemudian diubah warnanya menjadi grayscale.

Analisis data dengan NTSYSpc 2.1. Scoring pita-pita DNA. Data diubah menjadi matriks 0-1. Pita DNA yang muncul pada berat molekul tertentu, ditulis sebagai angka 1 dan pita yang tidak muncul ditulis sebagai angka 0 . Matriks ini dibuat dengan menggunakan program Microsoft excel. Data hasil scoring dari 11 primer RAPD digabung menjadi satu untuk digunakan dalam program NTSYSpc 2.1. Pembuatan matriks dengan program NTedit. Data hasil scoring seluruh primer yang telah ditulis pada program microsoft excel kemudian dipindah atau ditulis ulang pada program Ntedit. Pada matriks, baris merupakan ukuran pita-pita DNA (bp) dan kolom merupakan kultivar yang digunakan. Clustering dan konstruksi dendogram similaritas dengan NTSYSpc 2.1. Pengolahan data selanjutnya adalah untuk mengetahui indeks similaritas antar kultivar dan konstruksi dendogram similaritas. Data kemudian dianalisis dengan program NTSYS-pc (Numerical Taxonomy and Multivariate Analysis System, Version 2.10). Indeks similaritas dihitung dari data biner dengan rumus Simple matching coefficient $\left(\mathrm{S}_{\mathrm{SM}}\right)$. Dendogram dibentuk dengan algoritma pengklasteran Unweighted Pair-Group Method Arithmatic Average (UPGMA) (Singh, 1999).

\section{HASIL}

Tabel 1. Primer RAPD yang digunakan dalam penelitian (Sensoy et al., 2007)

\begin{tabular}{|c|c|c|}
\hline No & Primer & Primer Sequence 5' - 3' \\
\hline 1. & PMAR & $5^{\prime}$ - CAGACAAGCC - 3' \\
\hline 2. & BC-388 & 5' - CGGTCGCGTC - 3' \\
\hline 3. & BC-551 & $5^{\prime}-$ GGAAGTCCAC - $3^{\prime}$ \\
\hline 4. & $\begin{array}{l}\text { OPAK- } \\
16\end{array}$ & 5' - CTGCGTGCTC - 3' \\
\hline 5. & $\begin{array}{l}\text { OPAX- } \\
16\end{array}$ & 5' - GTCTGTGCGG - 3' \\
\hline
\end{tabular}

\begin{tabular}{clc}
\hline 6. & OPA-07 & 5' - GAAACGGGTG - 3' \\
\hline 7. & OPB-06 & 5' - TGCTCTGCCC - 3' \\
\hline 8. & OPD-13 & 5'- GGGGTGACGA - 3' \\
\hline 9. & OPR-01 & 5' - TGCGGGTCCT - 3' \\
\hline 10. & OPT-20 & 5' - GACCAATGCC - 3' \\
\hline 11. & OPAJ-18 & 5' - GGCTAGGTGG - 3' \\
\hline
\end{tabular}

OP: Operon Technologies; BC: Univ. British Columbia

Tabel 2. Komposisi formula PCR untuk FastStart PCR Master

\begin{tabular}{clcc}
\hline No. & Ramuan & $\begin{array}{c}\text { Vol per } \\
\text { sampel }\end{array}$ & konsentrasi \\
\hline 1. & Master mix & $11 \mu \mathrm{l}$ & \\
\hline 2. & $\begin{array}{l}\text { Primer } \\
\text { RAPD }\end{array}$ & $2,2 \mu \mathrm{l}$ & $25-100 \mu \mathrm{M}$ \\
\hline 3. & $\begin{array}{l}\text { DNA } \\
\text { template }\end{array}$ & $3 \mu \mathrm{l}$ & $70 \mathrm{ng}$ \\
\hline 4. & Akuabides & $3,8 \mu \mathrm{l}$ & \\
\hline \multicolumn{3}{l}{ Volume total } & $20 \mu \mathrm{l}$ \\
\end{tabular}

Tabel 3. Prosedur Reaksi PCR-RAPD

\begin{tabular}{clcc}
\hline No. & \multicolumn{1}{c}{ Reaksi } & Suhu & Waktu \\
\hline 1. & Predenaturation & $94{ }^{\circ} \mathrm{C}$ & 5 menit \\
\hline 2. & Denaturation & $94{ }^{\circ} \mathrm{C}$ & 1 menit \\
\hline 3. & Annealing & $36-39^{\circ} \mathrm{C}$ & 1 menit \\
\hline 4. & Elongation & $72{ }^{\circ} \mathrm{C}$ & 2 menit \\
\hline 5. & Post elongation & $72{ }^{\circ} \mathrm{C}$ & 10 menit \\
\hline 6. & Endless & $4{ }^{\circ} \mathrm{C}$ & 4 menit
\end{tabular}
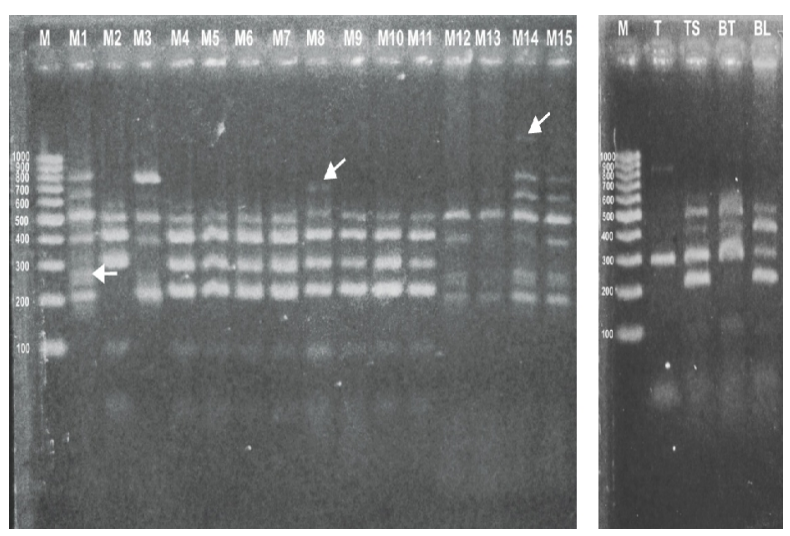

Gambar 1. Elektroforegram DNA hasil PCR RAPD dengan primer PMAR. M= marker $100 \mathrm{bp}$ (Fermentas), M1 $=$ GMB, M2 $=$ MG1, M3 $=$ PI 371795, M4= Andes, M5= Action, M6= Glamour, M7 $=$ MAI, M8 $=$ Ladika, M9= Astros, M10= Sumo, M11=Monami Red, M12= Elegant, M13= Fantasy, M14= Sky Rocket, M15= Virgo, $\mathrm{T}=$ timun, $\mathrm{TS}=$ timun suri, $\mathrm{BT}=$ barteh, dan $\mathrm{BL}=$ blewah 

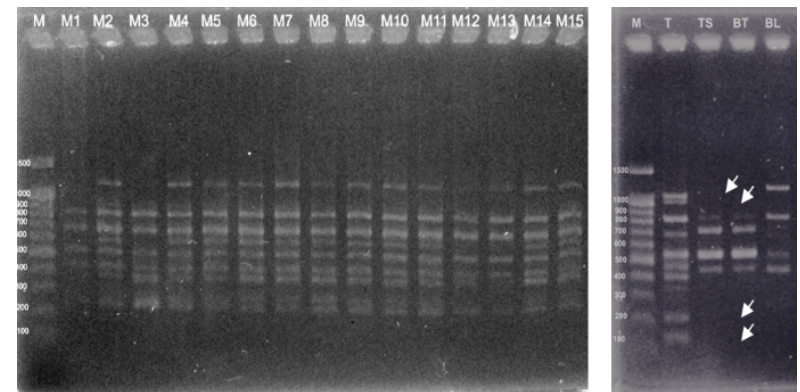

Gambar 2. Elektroforegram DNA hasil PCR RAPD dengan primer BC-551. M=marker $100 \mathrm{bp}$ (Bioron)

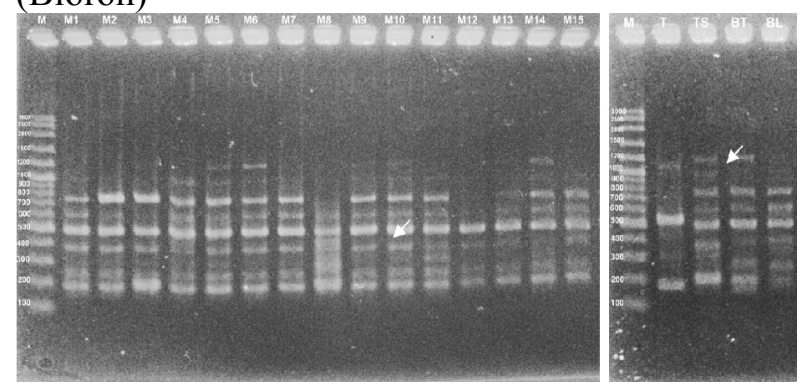

Gambar 3. Elektroforegram DNA hasil PCR RAPD dengan primer BC-388. M=marker $100 \mathrm{bp}$ (Vivantis)

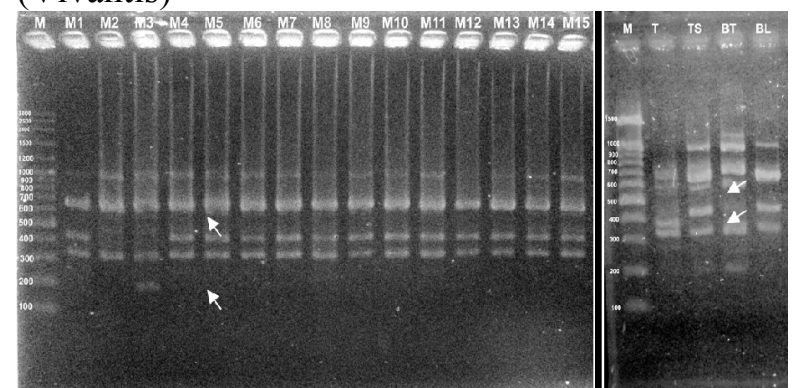

Gambar 4. Elektroforegram DNA hasil PCR RAPD dengan primer OPAK-16. $\mathrm{M}=$ marker 100 bp (Vivantis)

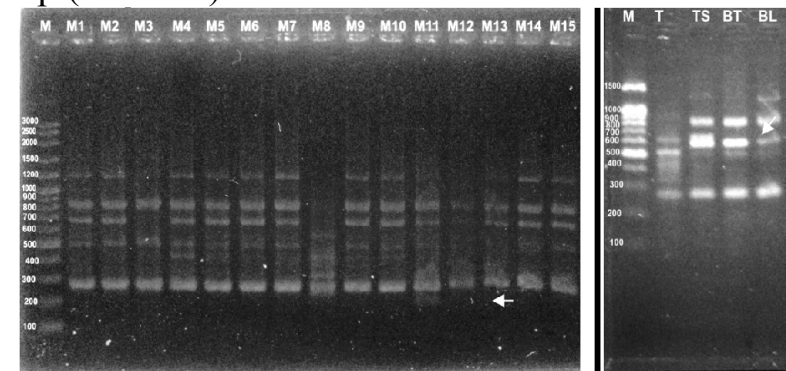

Gambar 5. Elektroforegram DNA hasil PCR RAPD dengan primer OPAX-16. $\mathrm{M}=$ marker 100 bp (Vivantis)
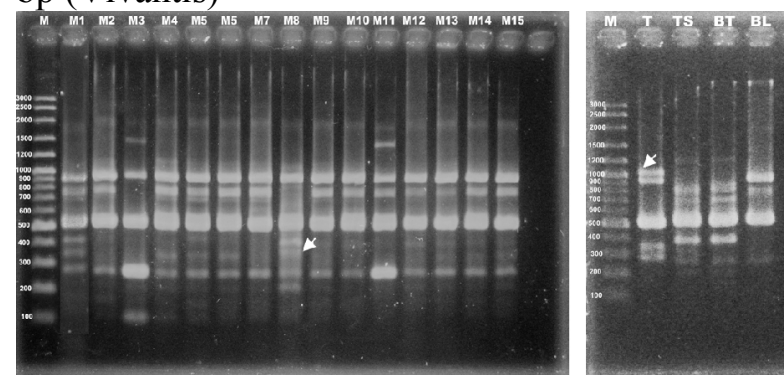

Gambar 6. Elektroforegram DNA hasil PCR RAPD dengan primer OPA-07. $\mathrm{M}=$ marker $100 \mathrm{bp}$ (Vivantis)

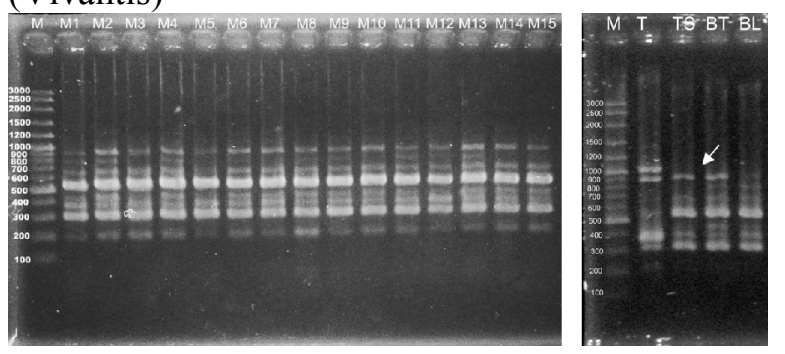

Gambar 7. Elektroforegram DNA hasil PCR RAPD dengan primer OPB-06. $\mathrm{M}=$ marker $100 \mathrm{bp}$ (Vivantis)
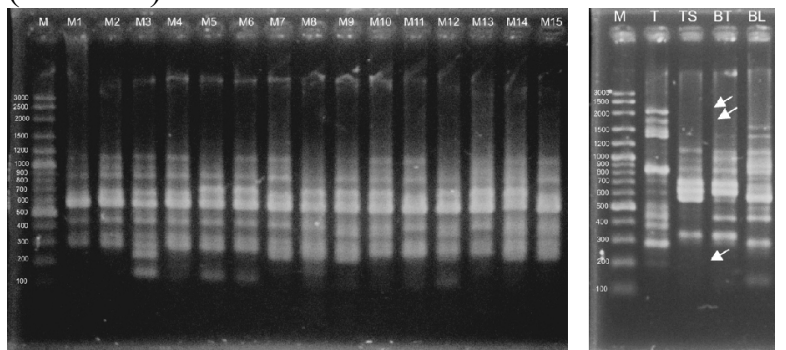

Gambar 8. Elektroforegram DNA hasil PCR RAPD dengan primer OPD-13. $M=$ marker $100 \mathrm{bp}$ (Vivantis)
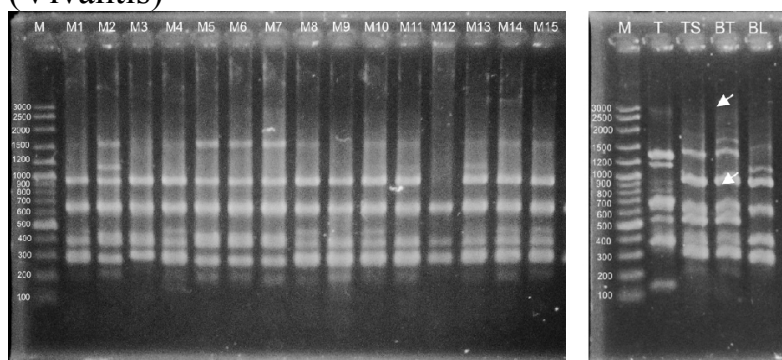

Gambar 9. Elektroforegram DNA hasil PCR RAPD dengan primer OPR-01. M=marker $100 \mathrm{bp}$ (Vivantis)
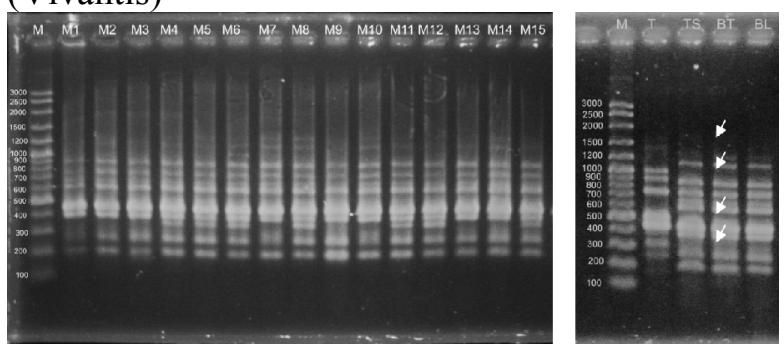

Gambar 10. Elektroforegram DNA hasil PCR RAPD dengan primer OPT-20. $\mathrm{M}=$ marker $100 \mathrm{bp}$ (Vivantis)

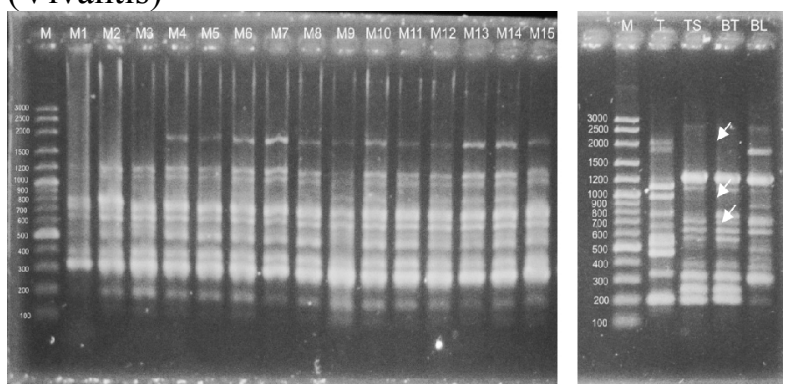


Gambar 11. Elektroforegram DNA hasil PCR RAPD dengan primer OPAJ-18. M=marker $100 \mathrm{bp}$ (Vivantis)

\section{PEMBAHASAN}

Sebelas primer RAPD digunakan pada penelitian, yaitu PMAR, BC-551, BC-388, OPAK-16, OPAX-16, OPA-07, OPB-05, OPD-13, OPR-01, OPT-20, dan OPAJ-18 (Tabel 1). Primer PMAR dipilih dari penelitian sebelumnya tentang pengembangan primer RAPD untuk mendeteksi gen resistensi tanaman melon terhadap powdery mildew (Daryono, et al., 2009). Sedangkan 10 primer RAPD lainnya dipilih melalui studi jurnal tentang diversitas genetik melon di Turki berdasarkan karakter fenotipik dan penanda RAPD (Sensoy et al., 2007). Tujuan penelitian tersebut adalah untuk mengelompokkan 400 aksesi melon ke dalam kelompok yang tergolong manis dan tidak manis. Pada penelitian tersebut digunakan 33 primer RAPD yang menghasilkan 1 - 9 DNA polimorfik. Sedangkan dalam penelitian ini dipilih 10 primer yang memiliki DNA polimorfik terbanyak dari 33 primer. Jumlah DNA template yang digunakan adalah $30 \mathrm{ng}$. Sedangkan dalam penelitian ini dilakukan optimasi terlebih dahulu untuk mendapatkan hasil PCR yang optimal, yaitu meliputi konsentrasi DNA template, konsentrasi primer, dan suhu annealing. Berdasarkan optimasi yang telah dilakukan, konsentrasi DNA template yang digunakan adalah $70 \mathrm{ng}$ (tabel 4). Pada primer BC-551 (Gambar 2) dihasilkan 17 fragmen DNA berukuran 1301200 bp. Fragmen DNA polimorfik yang dihasilkan berjumlah 15 dan 2 fragmen DNA monomorfik. Pola pita DNA GMB lebih mirip dengan PI 371795 sebagai salah satu tetua dalam persilangannya. DNA polimorfik spesifik untuk timun ditunjukkan oleh fragmen DNA berukuran 130, 200, 1000 dan 1100 bp. Visualisasi pita DNA untuk primer BC-388 dapat dilihat pada Gambar 3. Amplifikasi DNA dengan primer BC-388 menghasilkan 15 fragmen DNA dengan ukuran antara 190-1170 bp. Fragmen DNA tersebut keseluruhannya merupakan DNA polimorfik. Pada melon tidak ada fragmen DNA yang spesifik, tapi pada timun terdapat pita DNA yang spesifik, yaitu berukuran $1100 \mathrm{bp}$. Sedangkan untuk blewah, spesifik pada ukuran 320 bp. Melon Ladika berbeda dengan melon lainnya pada pita DNA $400 \mathrm{bp}$, meskipun juga dimiliki oleh timun, barteh, dan blewah.

Tabel 4. Hasil optimasi suhu dan konsentrasi primer untuk PCR RAPD

\begin{tabular}{clccc}
\hline No. & \multicolumn{1}{c}{ Primer } & Primer Sequence 5' $-3{ }^{\prime}$ & Suhu annealing $\left({ }^{\circ} \mathrm{C}\right)$ & Konsentrasi $(\mu \mathrm{M})$ \\
\hline 1. & PMAR & 5' - CAGACAAGCC - 3' & 37 & 100 \\
\hline 2. & BC-551 & 5' - GGAAGTCCAC - 3' & 36 & 25 \\
\hline 3. & BC-388 & 5' - CGGTCGCGTC - 3' & 37 & 75 \\
\hline 4. & OPAK-16 & 5' - CTGCGTGCTC - 3' & 38 & 75 \\
\hline 5. & OPAX-16 & 5' - GTCTGTGCGG - 3' & 38 & 50 \\
\hline 6. & OPA-07 & 5' - GAAACGGGTG - 3' & 39 & 50 \\
\hline 7. & OPB-06 & 5' - TGCTCTGCCC - 3' & 39 & 50 \\
\hline 8. & OPD-13 & 5'- GGGGTGACGA - 3' & 39 & 50 \\
\hline 9. & OPR-01 & 5' - TGCGGGTCCT - 3' & 39 & 50 \\
\hline 10. & OPT-20 & 5' - GACCAATGCC - 3' & 39 & 50 \\
\hline 11. & OPAJ-18 & 5' - GGCTAGGTGG - 3' & 39 & \\
\hline
\end{tabular}

Amplifikasi PCR RAPD dengan primer OPAK-16 (Gambar 4) diperoleh 12 fragmen DNA dengan ukuran 175 bp -1100 bp. Berdasarkan hasil didapatkan 10 fragmen DNA polimorfik dan 2 fragmen DNA monomorfik. Melon PI 371795 memiliki pita spesifik pada ukuran 175 bp. Fragmen DNA tersebut tidak terdeteksi pada kultivar GMB yang menunjukkan bahwa telah terjadi segregasi selama proses perakitan dan pemurnian melon GMB. Penggunaan primer OPAK-16 lebih bervariasi pada timun, timun suri, barteh, dan blewah. Timun memiliki fragmen DNA spesifik berukuran 385 dan 535 bp. Sedangkan pada barteh ditemukan fragmen DNA spesifik pada ukuran 200 dan 1100 bs. 
Jumlah DNA yang teramplifikasi dengan primer OPAX-16 (Gambar 5) ada 13 pita dengan ukuran 200 bp-1200 bp. Dua belas fragmen DNA merupakan polimorfik dan 1 fragmen DNA monomorfik. Monami Red memiliki pita DNA spesifik yang tidak dimiliki oleh kultivar melon lainnya, yaitu pada $200 \mathrm{bp}$. Fragmen DNA spesifik terdapat pada ukuran $630 \mathrm{bp}$ yang dimiliki oleh timun suri Amplifikasi DNA dengan PCR RAPD menggunakan primer OPA-07 (Gambar 6) dihasilkan 16 fragmen DNA, 14 DNA polimorfik dan 2 fragmen DNA monomorfik. Visualisasi pita DNA untuk primer OPA-07 dapat dilihat pada Gambar 6. Pada primer OPA-07, PI 371795 dan Monami Red memiliki pita DNA yang sama, yaitu pada $1460 \mathrm{bp}$, melon yang lain tidak memilikinya termasuk GMB. Fragmen DNA polimorfik spesifik terdapat pada melon Ladika dengan ukuran $350 \mathrm{bp}$.

Hasil amplifikasi PCR RAPD dengan primer OPB-06 (Gambar 7) menghasilkan jumlah fragmen DNA yang lebih sedikit dibanding primer lainnya, yaitu 9 fragmen DNA. Pita DNA monomorfik yang terbentuk oleh primer OPB-06 lebih banyak dari pada DNA polimorfik, 5 monomorfik dan 4 polimorfik. Polimorfisme yang rendah dari amplifikasi dengan primer OPB-06 akan menghasilkan variasi genetik yang rendah. Fragmen DNA berukuran 1025 bp bersifat spesifik untuk timun.

Penggunaan primer OPD-13 (Gambar 8) menghasilkan 21 pita DNA teramplifikasi dengan ukuran 135-2000 bp. Fragmen DNA polimorfik berjumlah 20 dan 1 fragmen DNA monomorfik. Pada pita DNA ukuran 200, 1700, dan 2000 bp, OPD-13 menjadi primer spesifik untuk timun. Selain itu pada ukuran 650 dan 900 bp menjadi spesifik untuk blewah. Dalam penelitian Dalam penelitian analisis penyimpangan genetik pada Cucumis spp. dengan marker RAPD, primer OPD-13 menghasilkan 41 pita DNA dan 5 alel (Lang et al., 2007). Hasil PCR RAPD menggunakan primer OPR-01 (Gambar 9) diperoleh 15 fragmen DNA berukuran 125-3000 bp, 12 fragmen DNA merupakan polimorfik dan 3 fragmen DNA adalah monomorfik. Empat
DNA polimorfik spesifik dihasilkan, yaitu 800 dan 3000 bp untuk timun, 1500 bp untuk blewah, serta 1650 bp untuk barteh.

Hasil PCR RAPD dengan primer OPT-20 (Gambar 10) diperoleh 16 fragmen DNA yang terdiri dari 11 fragmen DNA polimorfik dan 5 fragmen DNA monomorfik. Empat fragmen DNA spesifik terdeteksi pada timun dengan ukuran 320 bp, 500 bp, 1000 bp, dan 1520 bp. Penggunaan primer OPT-20 untuk kelompok melon tidak menghasilkan fragmen DNA yang bervariasi karena lebih banyak bersifat monomorfik (Tabel 6). Penggunaan primer OPT-20 dalam penelitian yang dilakukan Sensoy et al. (2007) menghasilkan 5 pita DNA polimorfik berukuran 650, 750, 1000, 1100, dan 1200 bp. Pada primer OPAJ-18 (Gambar 11) menghasilkan 19 fragmen DNA teramplifikasi berukuran 200-2600 bp. Dari 19 fragmen DNA yang dihasilkan, 15 fragmen DNA merupakan polimorfik $(78,95 \%)$ dan 4 fragmen DNA monomorfik. Tiga DNA polimorfik spesifik terdeteksi pada timun dengan ukuran 675, 1000, dan 2025 bp. Sedangkan fragmen DNA spesifik pada blewah berukuran 425 dan 890 bp. Sepuluh fragmen DNA yang teramplifikasi pada melon, 7 di antaranya adalah monomorfik. Dengan demikian primer OPAJ-18 baik digunakan untuk menganalisis variasi genetik anggota Cucurbitaceae.

Polimorfisme DNA Hasil PCR RAPD. Keanekaragaman genetik pada melon, timun, timun suri, barteh, dan blewah ditunjukkan dari perbedaan jumlah fragmen DNA yang teramplifikasi pada masing-masing primer. Berdasarkan hasil scoring dari masing-masing primer, diperoleh data polimorfisme DNA untuk 15 kultivar melon, timun, timun suri, barteh, dan blewah pada Tabel 5. Hasil yang berbeda juga ditujunjukkan apabila 11 primer ini hanya digunakan untuk membandingkan antar kultivar melon saja. Polimorfisme yang terbentuk dari 11 primer untuk 15 kultivar melon dapat dilihat pada Tabel 6. Primer yang efektif untuk digunakan dalam analisis variasi genetik melon adalah 7 primer yang memiliki persentase polimorfik lebih dari $50 \%$. Semakin banyak pita DNA polimorfik yang terbentuk, berarti menunjukkan variasi genetik 
yang beragam. Sehingga secara genotip, suatu individu dapat dibedakan dengan individu yang lainnya.

Hubungan Fenetik Melon Kultivar Gama Melon Basket dengan Melon Komersial Berdasarkan RAPD. Berdasar dendogram similaritas (Gambar 12) dapat dilihat bahwa pengelompokan genotip terbentuk pada tingkat kemiripan 0,52-0,94. Pada tingkat kemiripan rata-rata 0,70 didapatkan empat kelompok yaitu antara melon, blewah, timun, dan kelompok timun suri dan barteh. Timun (Cucumis sativus L.) berbeda spesies dengan melon (Cucumis melo L.), blewah, barteh, dan timun suri, sehingga terpisah secara genetik pada koefisien similaritas 0,52. Timun (C. sativus L.) memiliki jumlah kromosom $2 \mathrm{n}=14$ dan melon memiliki jumlah kromosom $2 \mathrm{n}=24$. Timun suri dan barteh memiliki koefisien similaritas pada tingkat 0,873 dan terpisah dengan timun, melon dan blewah. Timun suri bukanlah timun walaupun bentuk buahnya memanjang dan menyerupai timun. Blewah sendiri juga terpisah dengan kelompok melon komersial. Kelompok selanjutnya yang ditunjukkan dalam dendogram (Gambar 33) adalah melon. Munger \& Robinson (1991) berdasarkan taksonomi Naudin membagi $C$. melo L. menjadi varietas liar (wild) yaitu $C$. melo var. agrestis dan enam varietas budidaya atau kultivar, yaitu cantaloupensis, inodorus, conomon, dudaim, flexuosus dan momordica. Pada 15 kultivar melon, terlihat melon PI 371795 terpisah dengan jenis melon lainnya. Melon PI 371795 (progenitor PI 414723) Sehingga melon jenis ini sering digunakan sebagai indukan dalam pemuliaan tanaman untuk menghasilkan melon tahan jamur dan tahan virus.
Kultivar Gama Melon Basket secara genetik berbeda dengan melon komersial lainnya. Asal mula kultivar diperoleh dari persilangan antara Andes dan PI 371795 sebagai tetuanya. PI 371795 digunakan sebagai indukan dalam perakitan Gama Melon Basket karena diharapkan kedua kultivar tersebut mewarisi sifat ketahanan terhadap jamur dan virus, sehingga dapat dijadikan benih unggul di Indonesia. Gama Melon Basket adalah hasil pemurnian dari persilangan F2B5 (salah satu keturunan dari $\mathrm{F}_{1} \mathrm{~B} \times \mathrm{F}_{1} \mathrm{~B}$ ) dengan TC4. Berdasarkan indeks similaritas, Gama melon Basket dengan PI 371795 memiliki tingkat similaritas sebesar 8,37 dan antara Gama Melon Basket dengan Andes memiliki tingkat kemiripan yang sama, yaitu sebesar 8,37. Dengan demikian dapat dikatakan bahwa Gama Melon Basket secara genetik memiliki kemiripan lebih besar terhadap PI 371796. Kemiripan sifat yang ditunjukkan dengan dendogram bersifat fenetik, dan bukan bersifat filogenetik Semakin banyak persamaan karakter morfologi semakin dekat hubungan kekerabatannya, sebaliknya semakin sedikit persamaan karakter morfologi yang dimiliki, maka semakin jauh kekerabatannya (Sokal and Sneath, 1973). Selain morfologi, karakter molekular seperti penggunaan penanda RAPD dapat memperkuat data hubungan kekerabatan suatu organisme uji berdasarkan analisis variasi genetik yang dimiliki. Penanda molekular dapat memberikan gambaran hubungan fenetik yang lebih akurat dibanding hubungan fenetik yang didasarkan atas karakter morfologi saja. Hal ini disebabkan analisis terhadap genom atau DNA lebih stabil karena tidak dipengaruhi oleh faktor lingkungan.

Tabel 5. Polimorfisme DNA yang terdeteksi pada 11 primer RAPD untuk 18 kultivar

\begin{tabular}{clcccc}
\hline No & Primer & $\begin{array}{c}\text { Jumlah fragmen } \\
\text { DNA }\end{array}$ & $\begin{array}{c}\text { DNA } \\
\text { polimorfik }\end{array}$ & $\begin{array}{c}\text { DNA } \\
\text { monomorfik }\end{array}$ & $\begin{array}{c}\text { Persentase DNA polimorfik } \\
(\%)\end{array}$ \\
\hline 1 & PMAR & 12 & 12 & 0 & 100,00 \\
\hline 2 & BC-551 & 17 & 15 & 2 & 88,24 \\
\hline 3 & BC-388 & 15 & 15 & 0 & 100,00 \\
\hline 4 & OPAK-16 & 12 & 10 & 2 & 83,33 \\
\hline 5 & OPAX-16 & 13 & 12 & 1 & 92,31 \\
\hline 6 & OPA-07 & 16 & 14 & 2 & 87,50 \\
\hline 7 & OPB-06 & 9 & 4 & 5 & 44,44 \\
\hline
\end{tabular}




\begin{tabular}{rlllll}
\hline 8 & OPD-13 & 21 & 20 & 1 & 95,24 \\
\hline 9 & OPR-01 & 15 & 12 & 3 & 80,00 \\
\hline 10 & OPT-20 & 16 & 11 & 5 & 68,75 \\
\hline 11 & OPAJ-18 & 19 & 15 & 4 & 78,95 \\
\hline & & & & \\
\hline & & 140 & 25 & 84,85 \\
\hline
\end{tabular}

Tabel 6. Polimorfosme DNA yang terdeteksi pada 11 primer RAPD untuk 15 kultivar melon

\begin{tabular}{llcccc}
\hline No & Primer & $\begin{array}{c}\text { Jumlah fragmen } \\
\text { DNA }\end{array}$ & $\begin{array}{c}\text { DNA } \\
\text { polimorfik }\end{array}$ & $\begin{array}{c}\text { DNA } \\
\text { monomorfik }\end{array}$ & $\begin{array}{c}\text { Persentase DNA polimorfik } \\
(\%)\end{array}$ \\
\hline 1 & PMAR & 12 & 10 & 2 & 83,33 \\
\hline 2 & BC-551 & 9 & 5 & 4 & 55,56 \\
\hline 3 & BC-388 & 10 & 5 & 5 & 50,00 \\
\hline 4 & OPAK-16 & 7 & 5 & 2 & 71,43 \\
\hline 5 & OPAX-16 & 10 & 7 & 3 & 70,00 \\
\hline 6 & OPA-07 & 14 & 10 & 4 & 71,43 \\
\hline 7 & OPB-06 & 8 & 2 & 6 & 25,00 \\
\hline 8 & OPD-13 & 12 & 7 & 5 & 58,33 \\
\hline 9 & OPR-01 & 9 & 5 & 4 & 55,56 \\
\hline 10 & OPT-20 & 13 & 4 & 8 & 30,77 \\
\hline 11 & OPAJ-18 & 10 & 3 & 7 & 55,00 \\
\hline jumlah & 114 & 63 & 50 &
\end{tabular}

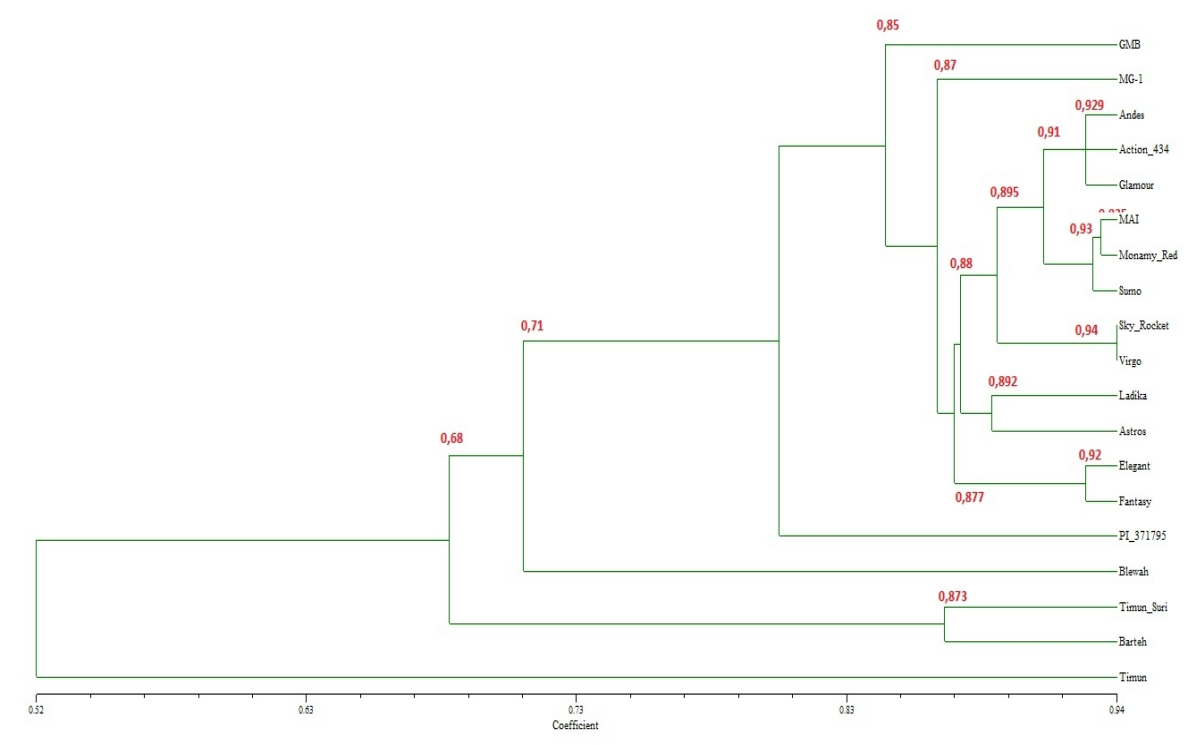

Gambar 12. Dendogram similaritas dari 15 kultivar melon, timun, timun suri, barteh, dan blewah berdasar karakter molekular dengan metode UPGMA

\section{KESIMPULAN}

1. Penanda molekular RAPD yang terdiri dari 11 primer dapat digunakan untuk menganalisis variasi genetik pada 15 kultivar melon dengan timun, timun suri, barteh, dan blewah.
2. Berdasarkan dendogram similaritas yang dihasilkan, dapat diketahui hubungan kekerabatan antar jenis melon dan dengan varietas lain seperti timun, timun suri, barteh, dan blewah. Melon kultivar GMB berbeda dengan kultivar melon lainnya, 
sehingga layak untuk dilepas sebagai kultivar melon unggulan yang baru.

3. Melon kultivar GMB memiliki frgamen DNA spesifik pada ukuran 295 bp dengan primer PMAR. Sepuluh primer RAPD lainnya tidak membentuk fragmen DNA polimorfik spesifik untuk kultivar GMB.

\section{DAFTAR PUSTAKA}

Alaydrus Y. 2008. Pemuliaan dan Pewarisan Sifat Ketahanan Terhadap Kyuri Green Mottle Mosaic Virus (KGMMV) pada Melon (Cucumic sativus L.). [Tesis]. Yogyakarta: Fakultas Biologi Universitas Gadjah Mada. hal 5-7, 13-15, 56-57, 7577.

Campbell NA, Reece JB and Mitchell LG. 2000. Biologi. Edisi Kelima. Jakarta: Erlangga. hal 395-396.

Daryono BS. 2006. Resistance to Cucurbit Viruses in Several Genotypes of Melon (Cucumis melo L.). Berkala Ilmiah Biologi. vol 5(1):1-12.

Daryono BS, Aristya GR and Kasiamdari RS. 2009. Development of Random Amplified Polymorphism DNA Markers Linked to Powdery Mildew Resistance Gene in Melon. Yogyakarta: Fakultas Biologi Universitas Gadjah Mada
Garcia J, Oliver M, Paniagua $\mathrm{HG}$ and de Vicente MC, 2000. Comparing AFLP, RAPD and RFLP markers for Measuring Genetic Diversity in Melon. Theor Appl Genet. vol 1 (101): 860-864

Jing-feng C, Fei-yun Z, Ming-Hui L, Chun-tao $\mathrm{Q}$ and Gang R. 2003. Phylogenetic Relationship in Cucumis (Cucurbitaceae) Revealed by SSR and RAPD Analysis. Acta phytotaxanomica Sinica. vol 41 (5): 427-435.

Mas JG, Oliver M, Paniagua $\mathrm{HG}$ and de Vicente M.C. 2000. Comparing AFLP, RAPD, and RFLP Markers for Measuring Genetic Diversity in Melon. Theor Appl Genet. vol (101): 860-864.

Matsui T, kosugi Y, Yanagi T, Suzuki P, Bhowmik K and Sukarakarn S. 2002. Classification of Oriental Melon by RAPD Analysis. Pakistan Journal of Biological Science. vol 5 (2): 208-211.

Mliki A, Staub JE, Zhangyong S and Ghorbel A. 2003. Genetic Deversity in African Cucumber (Cucumis sativus L.) Provides Potential for Gerplasm Enhancement. Genetic Resources and Crop Evaluation. vol 1 (50): 461-468. 